ences, this well written new edition in its attractive two column format makes easy and stimulating reading. Without any hesitation I can therefore recommend this book to all those interested, pathologists included, in the pursuit of a better understanding of diseases of the nervous system.

DI GRAHAM

Sickle Cell Disease. GR Serjeant. (Pp 478; £35.) Oxford University Press. 1986.

This is a special book that not only should be read by anyone concerned with sickle cell disease but will be read with pleasure by all those who appreciate a well produced medical monograph. The unique experience of the author and his team in Jamaica is here for all to share. He guides us through the literature, including the molecular pathology and the clinical and laboratory problems of management. He leaves us in no doubt of his personal opinions but at the same time refers us to other workers' reviews in copious references. Each chapter presents a review of a particular aspect from pathophysiology, diagnosis, and epidemiology to those on bones and joints, the gut, the lungs, and the renal system. The entire volume is lavishly illustrated with clinical photographs, laboratory material, $\mathrm{x}$-rays, isotope scans, angiograms, and, indeed, anything that is needed to emphasise the author's point. The chapters on clinical management of the painful crisis, surgery, and the problems of pregnancy, give practical guidance based both on personal practice and published data. The comments on screening and sickle cell clinics are particularly timely with the current developments in genetic counselling. This is a reference work that is likely to be in common use rather than left to gather dust on the shelf.

A JACOBS

\section{Special Topics in Endocrinology and Metabo-} lism. Vol 7. Ed Margo P Cohen, Piero $P$ Foa. (Pp 280; £43.) Alan R Liss Inc. 1985. ISBN 0-8451-0706-2.

This series must be compared with that of Clinics in Endocrinology and Metabolism (Saunders, three monthly; about $250 \mathrm{pp}$ and f8 per issue); Endocrine Reviews (Williams and Wilkins, three monthly; about $100 \mathrm{pp}$ and $f 11$ per paper bound issue); Monographs in Endocrinology (Springer Verlag, four monthly; about $150 \mathrm{pp}$ and $£ 30$ per issue). There are also less frequent publications such as Recent Advances in Endocrinology and Metabolism.

There is nothing original in the aim of this book. Here is a collection of isolated essays by authorities, generally comprehensive, written, presented, and referenced to high standards. The topics are ectopic hormones; zinc deficiency; peptide hormone administration; prostatic cancer therapy; prenatal diagnosis; abnormal puberty; hypothalamic hypogonadism. Some of the authors have written similar reviews elsewhere, to which readers may already have access.

Any prospective buyer, whether an individual or a library, must compare the cost of this book, for the material offered, against that of similar series.

DN BARON

Mononuclear Phagocytes. Characteristics, Physiology and Function. Ed Ralph van Furth. (Pp 829; £145.50.) Martinus Nijhoff. 1985. ISBN 0898387329.

This book comprises the proceedings of the fourth Leiden conference on the mononuclear phagocyte system. There is no more versatile mammalian cell than the mononuclear phagocyte. Current thinking, as reflected in this volume, suggests that this single cell type derived from a bone marrow stem cell, is almost infinitely adaptable and plays an important part in almost every defence mechanism mounted by mammalian organism. The versatility of the mononuclear phagocyte is well illustrated by its constantly changing phenotype, and this makes recognition of these cells extremely difficult.

The first two chapters of this volume suggest that, in mice at least, monoclonal antibodies that reliably recognise mononuclear phagocytes are at last emerging. This promising beginning is followed by further discussion of the surface properties of mononuclear phagocytes. Thereafter, related contributions are usefully grouped into subheaded sections dealing with a wide range of properties of these fascinating cells. Each contribution ends with a succinct summary followed by extremely useful, and not over abundant, references. At the end of each chapter there is a well edited short discussion by the conference participants. It is a tribute to the participants that these discussions are uniformly stimulating. Anybody with more than a passing interest in mononuclear phagocyte cells will want to have these proceedings available fo consultation.

The book is extremely well produced and easy to refer to: I detected no typographica errors, which must be rare for a book of this kind. Given the importance of the mono를 nuclear phagocyte, this is a book that shoula be available in every pathology departmen where there is an interest in these cells? Unfortunately, the price of this volume is prohibitive, even for university libraries Perhaps the publishers underestimated the appeal that a book of this kind would have $\vec{\omega}$ for I am certain that at a more competitive price it would command reasonable sales. 옹 PG ISAACSON

Praxis der Prostatazytologie. Technik und Diagnostik. W Leistenschneider, R Nageb (Pp 227; DM 190.) Springer-Verlag. 1984.

When it was first introduced, exfoliative cytology was regarded with some suspicion. or indifference by the classical histoo pathologist. Since then, the technicad difficulties discussed in detail in this atlas have largely been overcome, and the exame ination of smears or aspiration biopsies has contributed greatly to the earlier diagnosis of cancer of various organs. This excellentio produced atlas deals with the cytology of the prostate. Delicate surgical techniques are required for the collection of adequate speco mens, and these are described in the first part of the book by the authors, both prof fessors of urology at the Free University in Berlin. This is followed by techniques op processing and staining and a surprisingl\% detailed description of the microscope an $\Phi$ its uses. There is a brief section on the classification of carcinoma of the prostate The bulk of the atlas deals with the normat and neoplastic cytology of the prostate an\& is profusely illustrated, although comparas tive histological illustrations would have enhanced the interest of the histopathologist and assisted the trainee cytologist.

The final chapters deal with the applicar tion of modern morphometric methodpo Although the objective quantitative assessment of both cytological and histo logical specimens is important, the diagnosi is more often than not based on the quali tative first impression of the experience microscopist. Experience can only bee acquired by the study of large numbers $\bar{\alpha}$ specimens, but this book will serve as $\Phi$ reliable guide both for the beginner and the mature cytopathologist.

I FRIEDMAN 